\title{
25. PERMEABILITY VERSUS DEPTH IN THE UPPER OCEANIC CRUST: IN SITU MEASUREMENTS IN DEEP SEA DRILLING PROJECT HOLE 504B, EASTERN EQUATORIAL PACIFIC ${ }^{1}$
}

\author{
Roger N. Anderson, Lamont-Doherty Geological Observatory \\ Mark D. Zoback and Stephen H. Hickman, United States Geological Survey \\ and \\ Robin L. Newmark, Lamont-Doherty Geological Observatory²
}

\begin{abstract}
In situ permeabilities measured within the upper kilometer of oceanic crust in Hole 504B on the south flank of the Costa Rica Rift decrease exponentially from $10^{-13}$ to $10^{-14} \mathrm{~m}^{2}$ in Layer $2 \mathrm{~A}$ (the upper $150 \mathrm{~m}$ ) to $10^{15}$ to $10^{-17} \mathrm{~m}^{2}$ in Layer 2B (150-550 m into basement) and to $10^{-17} \mathrm{~m}^{2}$ and lower in Layer $2 \mathrm{C}$ (deeper than $550 \mathrm{~m}$ ). We estimate the permeability $(k)$ versus depth $(z)$ to vary as $k(z)=0.11 e^{(-z / 50)} \times 10^{-12} \mathrm{~m}^{2}$. If this permeability versus depth function is representative of the oceanic crust in general, then hydrothermal convection would be vertically stratified, with the most vigorous circulation confined to the shallowest pillow basalt layers of the crust. Use of a full suite of geophysical logsincluding borehole televiewer imagery and multichannel, full waveform sonic, nuclear, and variable spacing electrical resistivity logs-allows us to characterize the scale and interconnectedness of fractures, and the degree of infilling of these fractures by alteration minerals. In Hole 504B, we observe a relationship between permeability and fracture porosity, determined from the geophysical logs. If fractures with similar aspect ratios are encountered at other oceanic sites, prediction of the permeability of the oceanic crust to within an order of magnitude is possible from geophysical logs. In Hole 395A in the Atlantic, for example, in situ permeability measurements yielded values similar to those predicted by the logging relationships established in Hole 504B.
\end{abstract}

\section{INTRODUCTION}

Convection of seawater within the oceanic crust is now a well-established physical observation. From hot springs spewing forth $350^{\circ} \mathrm{C}$, mineral-laden "smoke" at the ridge axes (e.g., Macdonald and Luyendyk, 1981), to $50 \mathrm{Ma}$-seafloor in the Indian Ocean with the distinct heat flow "oscillations" characteristic of ridge flank convection (Anderson et al., 1979), to helium anomalies that are a distinct fingerprint of convection in 20-Ma sediments of the eastern Pacific (Sayles and Jenkins, 1982), the evidence continues to accumulate that this hydrothermal circulation is one of the dominant physical and chemical processes controlling aging of the oceanic crust. One third of all seafloor is thought to have active convection within its crust, and the other two thirds bears the unmistakable chemical signature of past hydrothermal activity (e.g., Staudigel and Hart, this volume). Yet the most fundamental physical parameter that controls the form, magnitude, and duration of ocean crustal convection is also the least understood: permeability. We know very little about the permeability versus depth function in the oceanic crust and how it varies with age and geography.

\footnotetext{
${ }^{1}$ Anderson, R. N., Honnorez, J., Becker, K., et al., Init. Repts. DSDP, 83: Washington (U.S. Govt. Printing Office),

2 Addresses: (Anderson, Newmark) Borehole Research Group, Lamont-Doherty Geological Observatory, Columbia University, Palisades, NY 10964; (Zoback) United States Geological Survey, 345 Middlefield Road, Menlo Park, CA 94025; (Hickman, present address) Department of Earth, Atmospheric, and Planetary Sciences, Massachusetts Institute of Technology, Cambridge, MA 20139.
}

In order to measure directly this crucial parameter, we have been conducting in situ flow tests in Deep Sea Drilling Project (DSDP) boreholes over the last four years: first in Hole 504B in the eastern Pacific on Legs 68 and 69 (Anderson and Zoback, 1982), then in Hole 395A on the Mid-Atlantic Ridge during Leg 78B (Hickman et al., in press), and again in Hole 504B on Legs 83 and 92 (reported later). Hole 504B has penetrated over $1 \mathrm{~km}$ into the upper oceanic crust and offers the first DSDP hole in which measurements of permeability can be made in Layers $2 \mathrm{~A}, 2 \mathrm{~B}$, and $2 \mathrm{C}$ of the crust.

In this chapter, we report permeability measurements made over the lower $750 \mathrm{~m}$ of Hole 504B during Leg 83, and we derive a permeability versus depth function from this and previous measurements made in this hole. We then examine geophysical logs from the hole to determine if they may be used to predict permeability by indirect means. The crucial parameters that we extract from these logs are the scale of fracturing, how interconnected these fractures are, and how much the infilling of alteration minerals has clogged the fractures. As will be shown, these logs offer great promise as a predictor of crustal permeability, at least to within an order of magnitude in accuracy.

This extension from direct to indirect measurement of permeability is essential if we are to discuss permeability versus depth and age in the oceanic crust on a large scale. The experimental procedure involved in direct permeability measurement is much too complex, time consuming, and frought with mechanical difficulty to be carried out extensively in the oceanic crust within 
the next several years. Geophysical logs are rather inexpensive and easy to obtain, however.

\section{THE EXPERIMENT}

Hole 504B (Fig. 1), is currently the deepest penetration into oceanic crust, reaching $1075.5 \mathrm{~m}$ sub-basement. The stratigraphic sequence encountered during drilling on Legs $68,69,70$, and 83 was a rubbly, pillow basalt interval just below $274.5 \mathrm{~m}$ of carbonate sediments (with chert stringers near the bottom). This upper pillow basalt interval contains several massive basaltic flow units with thicknesses on the order of several meters. Despite the flow units, the upper $150 \mathrm{~m}$ were both highly permeable and underpressured so that penetration of the relatively impermeable sedimentary lid during drilling resulted in drawdown of ocean bottom water into the formation (Anderson and Zoback, 1982; Becker et al., 1983). The source of the underpressures is believed to be a hydrothermal convection system that is active within the oceanic crust in this 5.9-Ma seafloor on the southern flank of the Costa Rica Rift. Anderson et al. (1982) have classified this stratigraphic sequence as belonging to Layer 2A.

Between $150 \mathrm{~m}$ and $550 \mathrm{~m}$ sub-basement (420 and $820 \mathrm{~m}$ below seafloor), the pillow basalts become more altered and less "rubbly." This interval is thought to be Layer 2B of the oceanic crust. At the base of this layer,

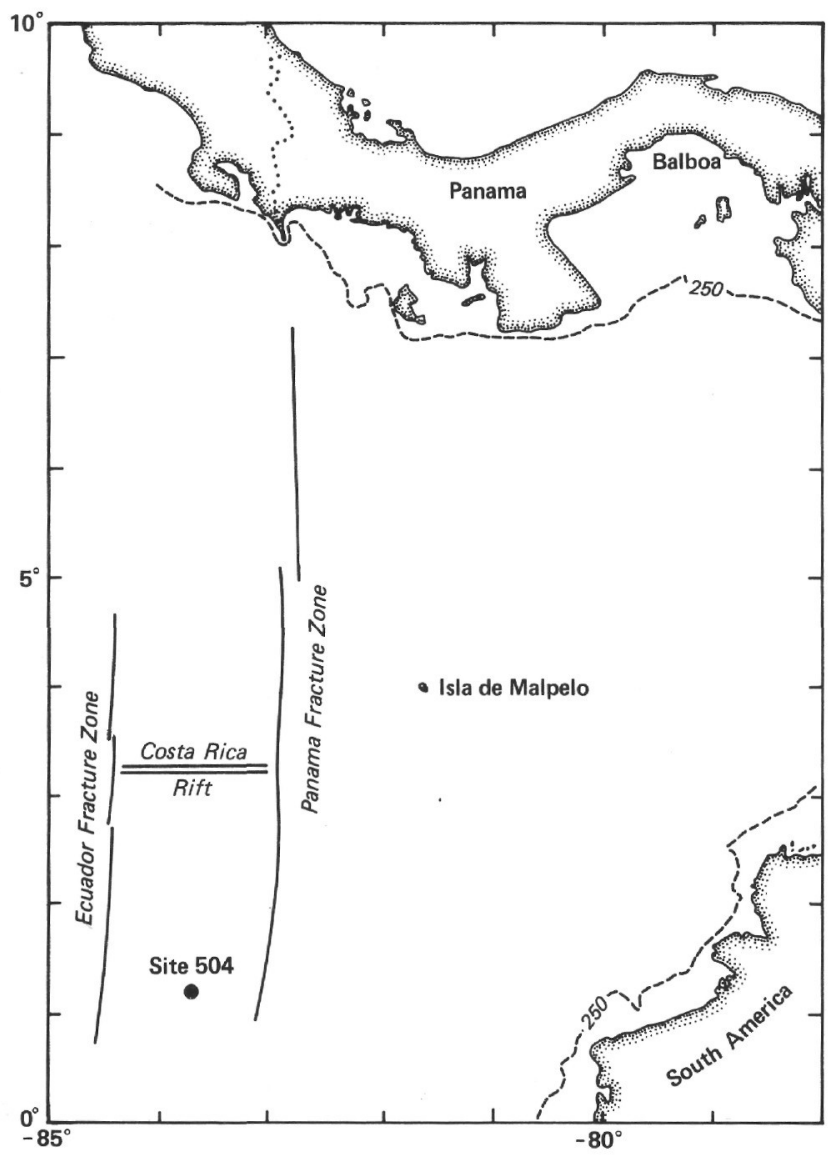

Figure 1. Location of Deep Sea Drilling Project Hole 504B. a transition zone of alternating pillow basalt and dike units is found. A metalliferous stockwork was also encountered within this zone. The lower $400 \mathrm{~m}$ of basement drilled in Hole 504B consist of a sheeted dike complex, so that the overall geology agrees with an "ophiolite" model for the structure of the oceanic crust (Anderson et al., 1982).

During Leg 69, we conducted "slug-type" permeability tests using an inflatable rubber packer to measure directly the decay of a pressure pulse forced first into Layer $2 \mathrm{~A}$, then into the top of Layer $2 \mathrm{~B}$. We measured bulk permeability values of $4 \times 10^{-14} \mathrm{~m}^{2}$ in the Layer $2 \mathrm{~A}$ interval of $50-200 \mathrm{~m}$ sub-basement, and $4 \times 10^{-15} \mathrm{~m}^{2}$ at $195-210 \mathrm{~m}$ sub-basement, which is at the top of Layer 2B (Anderson and Zoback, 1982).

In addition, the underpressures were measured and found to be 8-12 bars subhydrostatic within Layer $2 \mathrm{~A}$ (Anderson and Zoback, 1982). This underpressure, combined with flow rates into the "aquifer" calculated from depressed borehole temperatures, allowed for the calculation of a bulk permeability of $6 \times 10^{-14} \mathrm{~m}^{2}$ for the upper $100 \mathrm{~m}$ of Layer 2A (Becker et al., 1983).

The drop in permeability of over 1 order of magnitude explains why the ocean bottom water drawndown into the crust disappears into the Layer $2 \mathrm{~A}$ aquifer, but not into the deeper formations in the hole, and why temperatures deeper in the borehole are much higher than those in Layer 2A (Fig. 2). The higher temperatures are closer to those expected from a purely conductive geothermal gradient within the lower crust and would imply much lower permeability values for the oceanic crust below Layer $2 \mathrm{~A}$ than were measured at the top of Layer 2B (Becker et al., 1983).

\section{The Packer}

To test if permeability drops by several orders of magnitude within Layer 2 in Hole 504B, we attempted three types of hydrological experiments over the lower two thirds of Hole 504B. We were successful at setting a Lynes International during-drilling-safety-tool (DDST) rubber packer (Fig. 3A) $749 \mathrm{~m}$ above the bottom of the hole, when it had been drilled to a total depth of $1287.5 \mathrm{~m}$, and then forcing water down the drill pipe into the formation.

The DDST tool consists of a 1-m-long inflatable rubber packer, mounted from 2.3 to $3.3 \mathrm{~m}$ above the end of the drill string. The drill string is then lowered to the desired depth below which permeability is to be measured. A "go-devil" is then dropped down the inside of the pipe to lock into the packer body. Pumping then inflates the rubber element against the well bore. The packer is nothing more than a rubber plug that seals the annulus, or the portion of hole outside the drill pipe, so that water exiting the drill bit must go into the rock below the packer because the normal exit path out the annulus to the seafloor is blocked by the packer. A shear plug is then blown, opening the rig pumps to the formation below the packer. (See Anderson and Zoback, 1982; and Hickman et al., in press, for more details.)

The volume of water pumped into the formation is called a "slug" because the water pressure in the well 


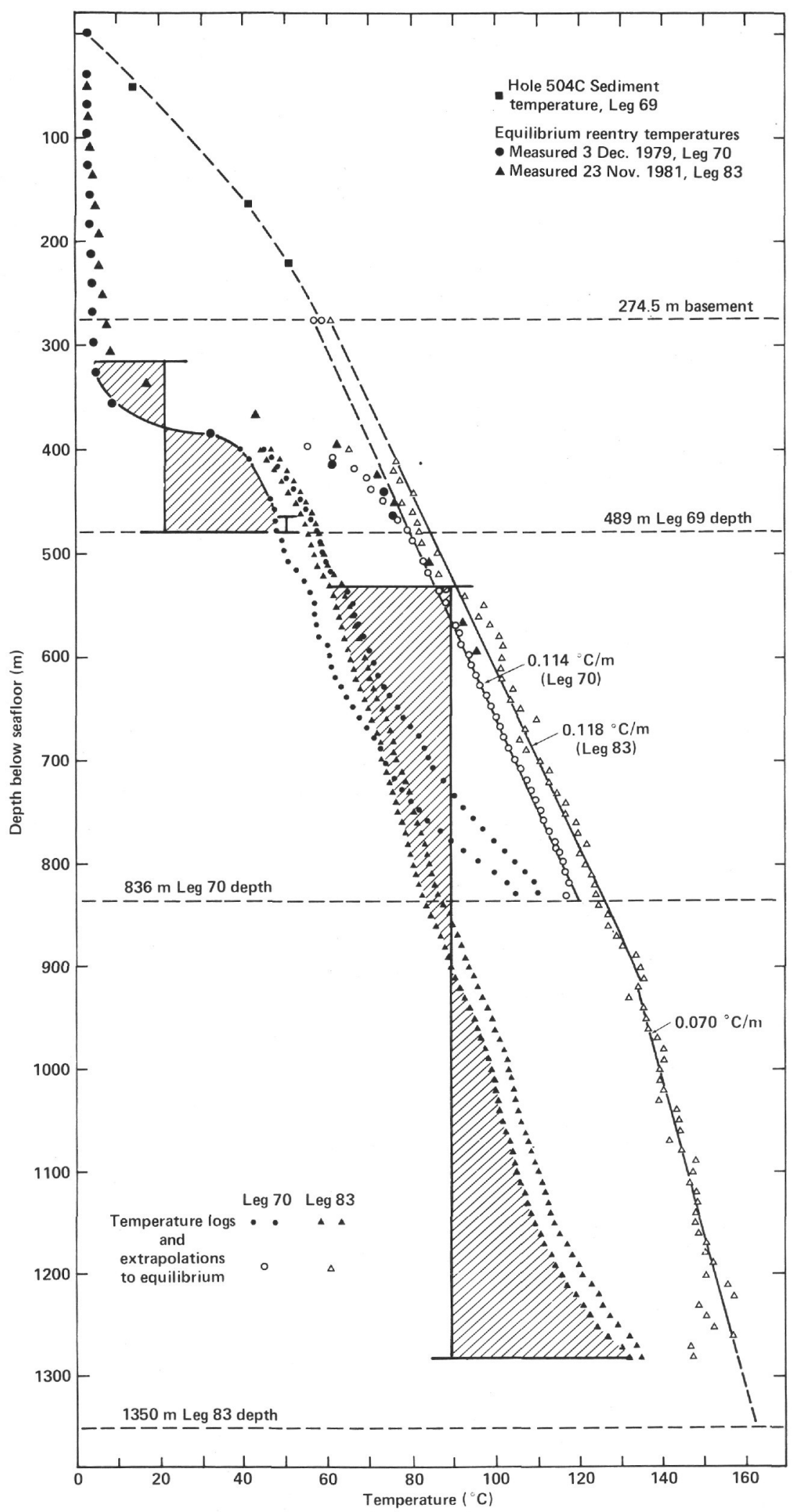

Figure 2. Temperatures measured at various times in Hole 504B. See Becker et al., 1983, and Becker et al., this volume, for details. The permeability test reported in this paper was over the lower $749 \mathrm{~m}$ of the hole, at the time it had been drilled to $1287.5 \mathrm{~m}$ below seafloor. We estimate that the average temperature of borehole water injected into the formation during that test was $90 \pm 30^{\circ} \mathrm{C}$. The tests from Anderson and Zoback, 1982, are also shown on this figure (solid bars just below sediment-basement interface). 


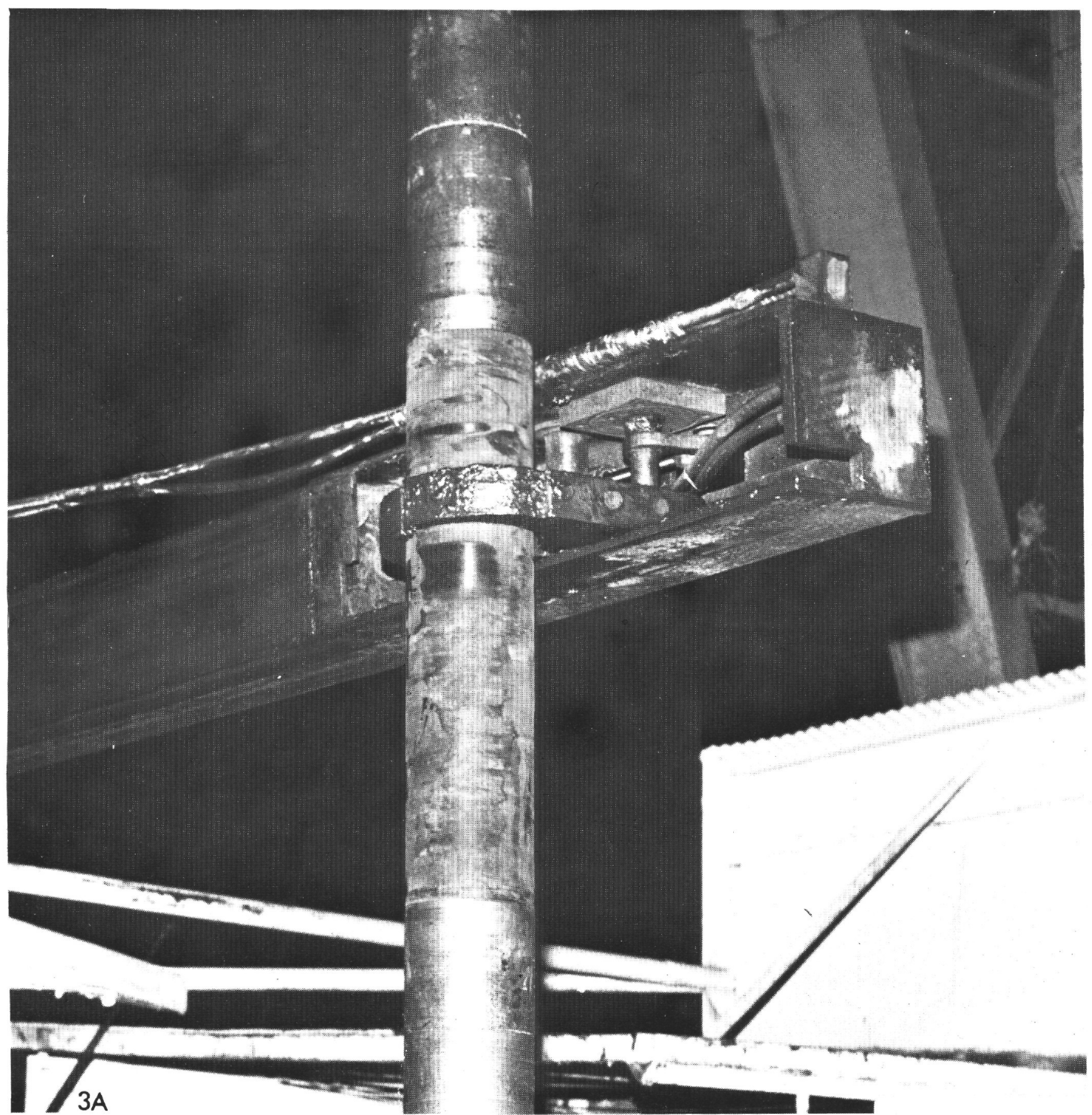

Figure 3. (A) Lynes packer just before lowering into bottom of Hole 504B. Rubber outer tread visible in center. (B) Lynes packer after return to surface from unsuccessful permeability test at bottom of Hole 504B. All the rubber has been lost from the packer, yet the steel strength member is still in place. It is suspected that the high temperatures at the bottom of the hole $\left(160^{\circ} \mathrm{C}, \mathrm{Fig} .2\right)$ caused the rubber to "devulcanize" from the packer. 


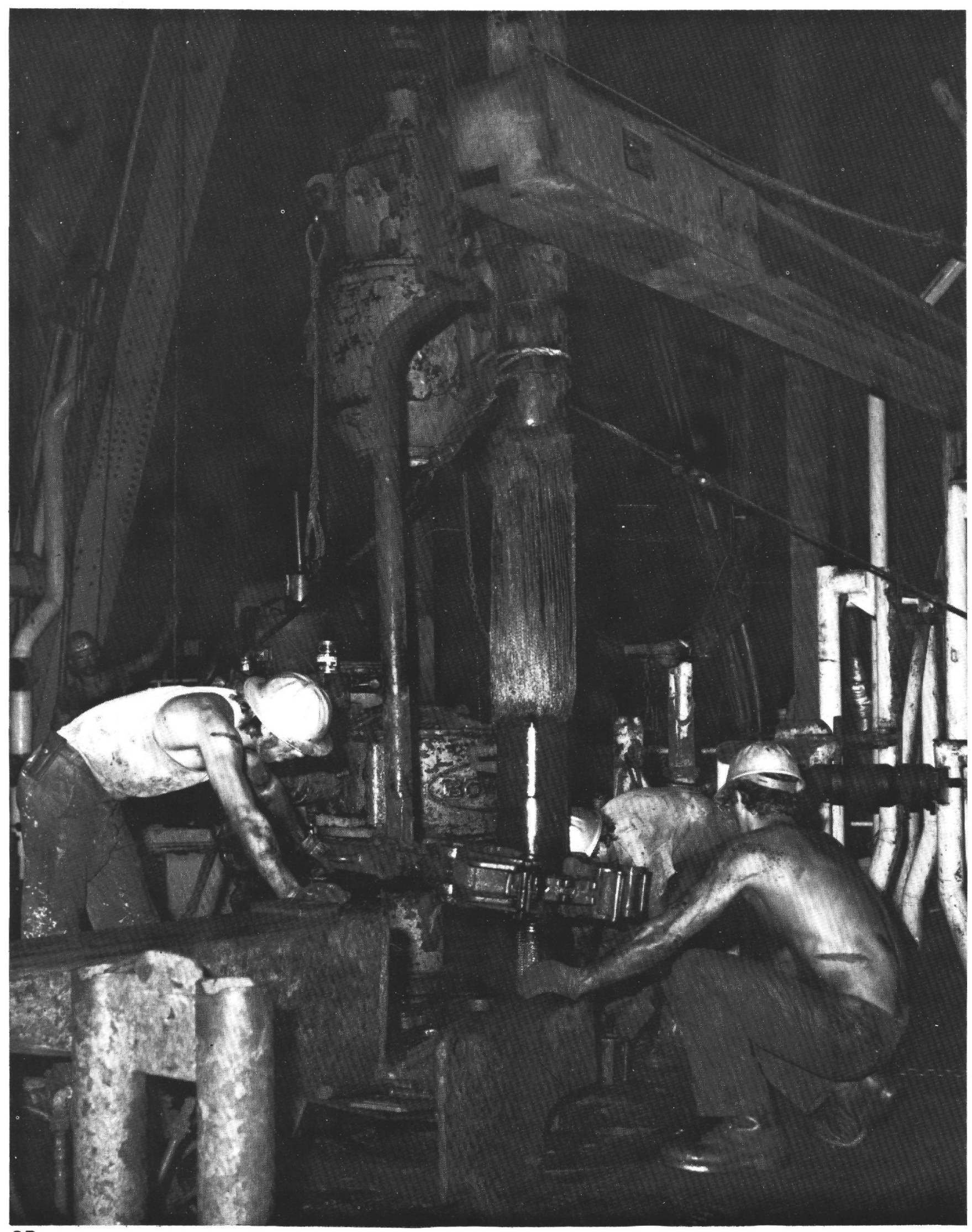

Figure 3. (Continued). 
bore is raised almost instantaneously. We then monitor the decay of this pressure slug, and the rate of return to normal formation pressures is a direct measure of the formation permeability. This permeability is a "bulk" measurement over the entire interval between the bottom of the hole and the location of the packer. The results of this test are described.

A second test, in which a constant flow rate is maintained into the formation below the packer, provides a measure of the permeability, if a stable downhole pressure is approached after several minutes of pumping. This test failed on Leg 83 when the packer seat against the well bore was weakened by the high formation temperatures, and leakage occurred at pressures higher than about 20 bars above hydrostatic.

In the third type of test, a sample of formation fluid is taken below the packed-off interval when a sample chamber containing air at 1 atmosphere is opened to the formation. Pressure is "drawn-down" in the well bore, and permeability is calculated from the rate of return of borehole pressure to normal. In all these tests, pressure is monitored in situ by placing a Kuster pressure gauge below the packer in a position open to the formation. This experiment also failed because the packer did not hold a seal.

Three rubber elements from the packer were destroyed trying to measure the bulk permeability within the sheeted dikes at the bottom of Hole 504B, the last failure occurring on Leg 92 . Borehole temperatures exceeding $140^{\circ} \mathrm{C}$ appear to have weakened (or "devulcanized") the rubber, leaving only the steel strength member and making a hydraulic seal impossible (Fig. 3B). Higher-temperature technology must be developed for the packer before we can measure permeability in the dikes at the bottom of Hole 504B. However, the successful measurement was over the entire lower $750 \mathrm{~m}$ of the borehole and contains important information on the permeability of the Layer $2 \mathrm{C}$ sheeted dikes.

\section{Slug-Test Theory}

Consider a well at hydrostatic pressure that is suddenly pressurized by injecting an additional amount of water with a high-pressure pump. The system is then shut in and the excess pressure $(H)$ following the initial pressure pulse $\left(H_{0}\right)$ is monitored as it decays with time $(t)$. It is assumed that flow into the tested interval is primarily radial and that the hydraulic properties of the formation remain constant throughout the test. Another assumption is that volumetric changes that are due to the expansion and contraction of components of the system other than the fluid are negligible. The normalized pressure decay $\left(H / H_{0}\right)$ is shown by Cooper et al. (1967) and Bredehoft and Papadopulos (1980) to be a function of two parameters, $\alpha$ and $\beta$, defined as:

$$
\alpha=\frac{\pi r_{s}^{2} S}{V_{w} C_{w} \rho_{w} g} \quad \beta=\frac{\pi T t}{V_{w} C_{w} \rho_{w} g}
$$

where

$$
\begin{aligned}
& r_{S}= \text { radius of the well bore, in } \mathrm{cm} ; \\
& S= \text { hydraulic storage coefficient of the tested in- } \\
& \text { terval; }
\end{aligned}
$$

$V_{w}=$ volume of water pressurized, in $\mathrm{cm}^{3}$;

$C_{w}=$ compressibility of water, in $\mathrm{cm}^{2} /$ dyne;

$\rho_{w}=$ density of water, in $\mathrm{g} / \mathrm{cm}^{3}$;

$g=$ acceleration due to gravity;

$t=$ time since initiation of pressure slug; and

$T=$ transmissivity of the formation.

Cooper et al. (1967), Papadopulos et al. (1973), and Bredehoeft and Papadopulos (1980) present a tabulation of the pressure-decay function $\mathrm{H} / \mathrm{H}_{0}$ as a set of type curves in which the shapes of different decay curves for varying $\alpha$ are shown as a function of $H / H_{0}$ and $\beta$ (see Anderson and Zoback, 1982, fig. 4). Permeability, $k$, is determined from the transmissivity, $T$, by

$$
k=T \frac{c}{b} \text { in } \mathrm{m}^{2},
$$

where $\mathrm{c}=\left[\mathrm{m} / \mathrm{g} \rho_{\mathrm{w}}\right] \times 10^{-4} \mathrm{~m}^{2} / \mathrm{cm}^{2} ; m=$ fluid viscosity, in poise; and $b=$ thickness of interval isolated by packer in $\mathrm{cm}$.

A semilogarithmic plot of $H / H_{0}$ versus time is superimposed on the type curves and translated along the $\beta$ axis into a position to best fit one of the $\alpha$ curves (see Cooper et al., 1967). The time, $t_{0}$, is read off at the point, $\beta=1$, where the slug-test data overlie the type curve for the appropriate $\alpha$. Then from equations (1) and (2):

$$
k=\frac{V_{w} C_{w} \rho_{w} g c}{\pi t_{0} b}
$$

As pointed out by Papadopulos et al. (1973), selection of the wrong type curve is a potential problem with the Cooper et al. (1967) method. However, such an error results in only a small corresponding error in the determination of $T$. It does result in a large error in the determination of $S$, however, and the slug test is considered an inaccurate method for the determination of aquifer storage coefficient. The type-curve fit is generally good enough to produce an accuracy in $T$ of approximately $\pm 33 \%$. We will produce an estimated error by intentionally misfitting the $\alpha$ curve by \pm 1 order of magnitude to produce error bars for our transmissivity values.

The comparison of the shape of the $H / H_{0}$ versus time curve to the type curve also gives a test of the success of the experiment. If a type curve cannot be fit to within 1 order of magnitude, and/or the shape of the slug-test curve differs significantly from that of the type curve, something went wrong with the experiment. Pressure-decay curves from experiments in which extreme leakage occurs around a damaged packer result in dramatically different curve shapes from those of the slug test.

In conducting multiple slug tests it is assumed that the decline in system head preceding the last slug has stopped before injection of the next slug test or that this declining head can be extrapolated to the end of the test without significant error. The initial head change $H_{0}$ is superimposed on this declining head and both $H_{0}$ and $H(t)$ of the next slug are measured above the previous test's projection (see Bredehoeft and Papadopolus, 1980). 
A failure to account for this changing datum can affect the shape of the data plot and thus result in an erroneous match to the type curves. In practice if the initial head decline has slowed down sufficiently, it is usually possible to extrapolate the "tail" from a preceding pressure transient through the slug test by fitting it to a simple linear or exponential function. Alternatively, if two complete slug tests occur one after the other, one may fit the first slug test to a type curve and use the projection of that type curve to approximate the head decline upon which the second pulse is superimposed. We will use this latter method.

\section{Slug-Test Results}

For the successful slug test, the packer element was set across a massive flow unit seen on the borehole-televiewer (BHTV) log (Newmark et al., this volume) at $4010 \mathrm{~m}$ below the rig floor (524 m BSF and $250 \mathrm{~m}$ into basement). Three consecutive slugs were injected into the formation: the first began at 12.5 bars above hydrostatic and was monitored for $730 \mathrm{~s}$, the second began at 15.5 bars above hydrostatic and was recorded for $734 \mathrm{~s}$, and the third, 14.6 bars for 717 s (Fig. 4). We then attempted a constant-rate flow test, but the packer then came unseated from the well bore, and the test failed.

The $H / H_{0}$ versus time plots from the slug test over the lower $749 \mathrm{~m}$ of Hole 504B agree well with curve shapes predicted by Cooper et al. (1967) (Fig. 5). For the permeability calculation of Equation (3), the volume of water pressurized $\left(7.8 \times 10^{7} \mathrm{~cm}^{3}\right)$ is the length of drill pipe from the surface to the drill bit $3 \mathrm{~m}$ below the packer times the interval cross-sectional area of the pipe, plus the length of open hole beneath the drill bit times the area of the open hole. Density and compressibility values for water at the Hole 504B test depth are taken as $1.05 \mathrm{~g} / \mathrm{cm}^{3}$ and $4.2 \times 10^{-11} \mathrm{~cm}^{2} /$ dyne, respectively, as in Hickman et al. (in press).
There are two contributions to error with which we are particularly concerned. First, error in fitting the proper $\alpha$ curve is estimated as discussed previously by "misfitting" the data with $\alpha$ curves 1 order of magnitude larger and smaller than the best fit for each test. Transmissivity values together with these errors are given in Table 1.

A second source of error arises because we do not have a firm idea what the temperatures are for the fluid injected into the test interval, and viscosity is strongly temperature dependent. The time between last circulation of the entire well and setting of the packer will determine the amount of reheating of the well-bore fluid as it rebounds to the formation equilibrium temperature. This well-bore fluid then is pumped into the formation. For the permeability test the drill string was pulled completely to the surface after the last circulation, and the packer was attached and run back into the hole. The amount of time elapsed was $26 \mathrm{hrs}$. A reasonable estimate of the water temperature in the well after that time comes from temperature logs run after similar delays during the logging program (Fig. 2).

We calculate the temperature dependent viscosity, as $0.1668 T^{-0.8987}$ in poise (Gartling, 1977; Gartling and Hickox, 1979). The likely average fluid temperature within the test interval is $90^{\circ} \mathrm{C}$ (Fig. 2). We estimate error introduced into the permeability calculation from uncertainty in temperature by calculating $k$ using viscosities at 60 and $120^{\circ} \mathrm{C}$. The latter is a likely maximum because it is the average formation temperature, and the former is the estimated temperature of water at the top of the test interval. We then combined the error introduced by uncertainties in temperature with errors introduced by possible mismatches to the type curve (in such a way as to maximize the composite error) to produce the permeabilities in Table 1. We calculate a composite permeability value for the lower $749 \mathrm{~m}$ of Hole 504B to be $1.4 \times$

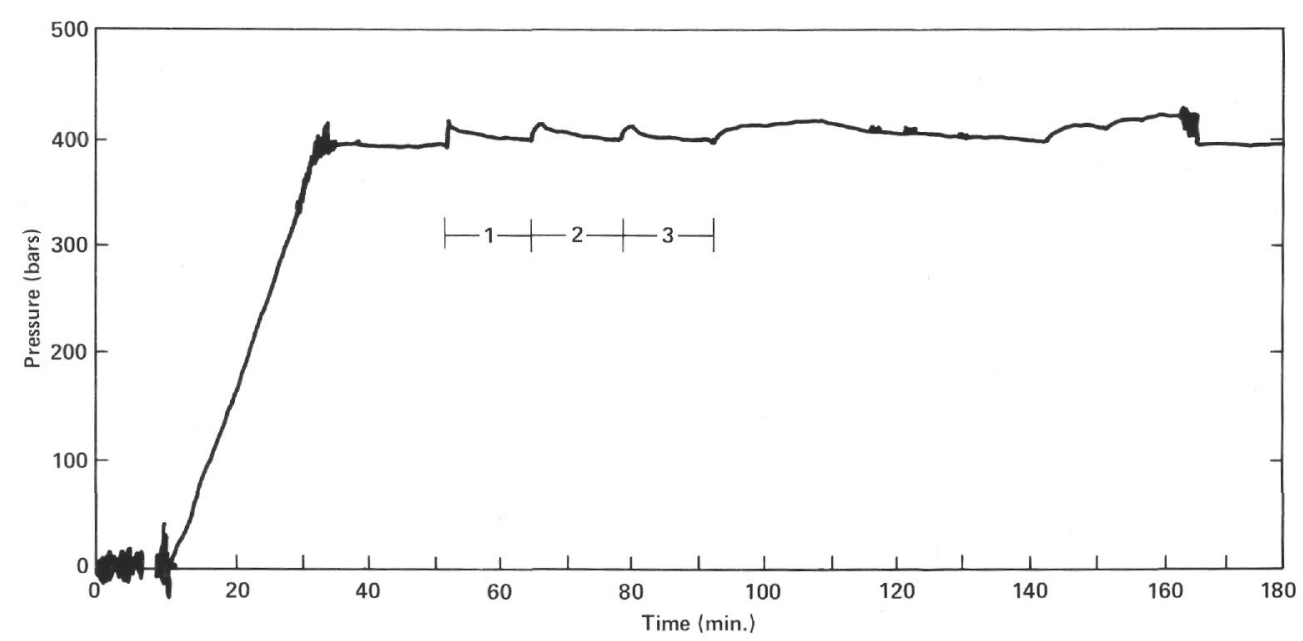

Figure 4. Pressure versus time record from the Kuster pressure gauge mounted below the packer within the test interval for the permeability measurement over the 538.5-1287.5 m interval of Hole 504B. 1, 2, and 3 indicate the pulse numbers in Table 1 . After Pulse 3, a constant-rate injection test was attempted, but the packer seal failed. The stylus reached the end of the record before the gauge returned to the surface, which explains why pressure did not return to atmospheric. 

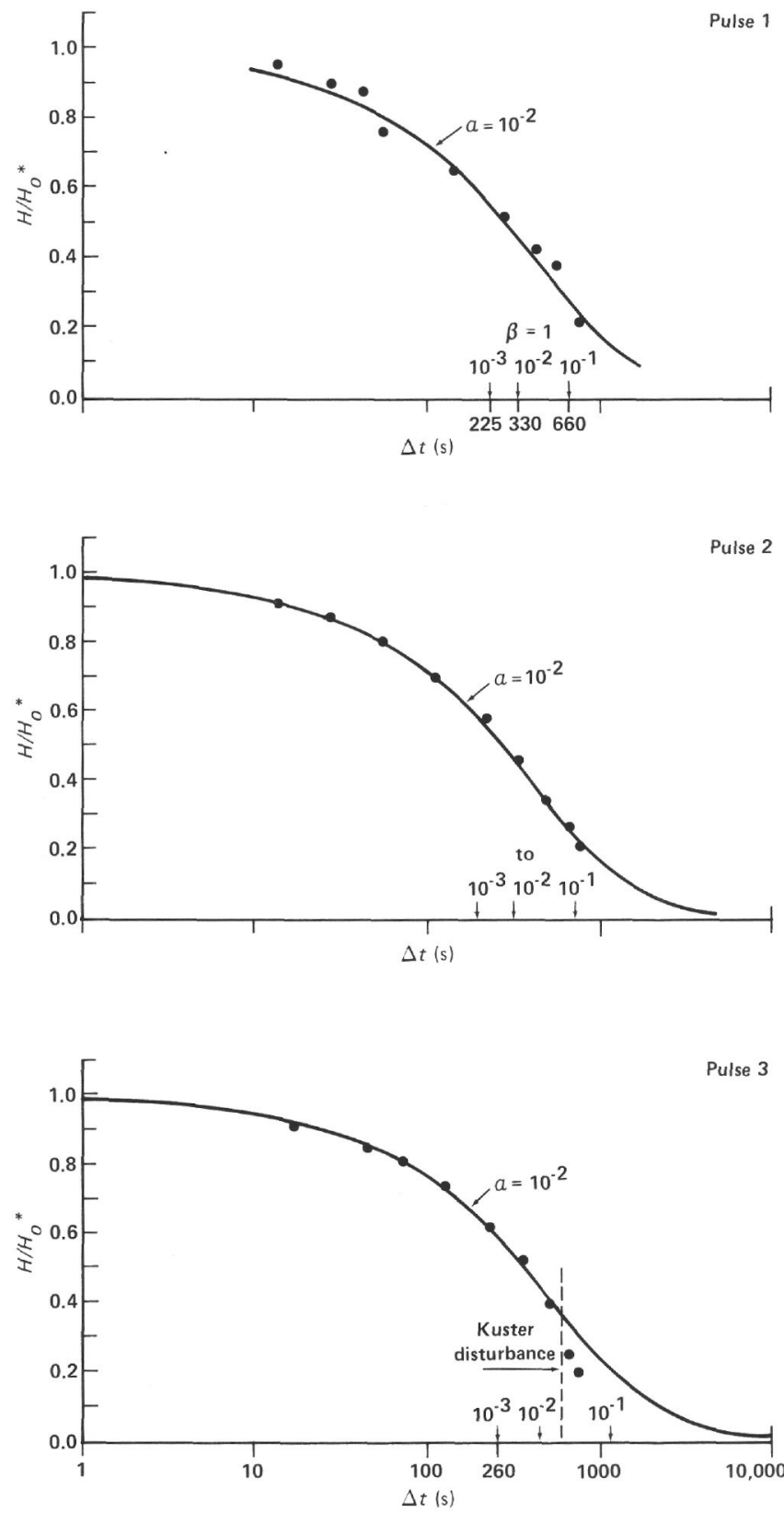

Figure 5. Pressure versus time curves for Pulses 1-3 of Figure 4 for permeability measurements over the lower $749 \mathrm{~m}$ of Hole 504B. Curves are from Cooper et al., 1967. Arrows indicate $t_{0}$ values for fits to various alpha curves. $H / H_{0}{ }^{*}$ indicates correction made for datum shift from residual of last pulse.

$10^{-17} \mathrm{~m}^{2}$ from the average of all values calculated in Table 1. Because Anderson and Zoback (1982) completed the permeability tests in the shallow portion of the hole before the lower $800 \mathrm{~m}$ were drilled, they were unaware of the rapid temperature increase below the aquifer in Layer $2 \mathrm{~A}$. They then used viscosity for $20^{\circ} \mathrm{C}$ water for all their calculations. While this is a reasonable value for the constant-rate flow test from 50 to $200 \mathrm{~m}$ into basement (see Fig. 2), the two slug tests at 190 to $210 \mathrm{~m}$ injected hotter waters than these into the formation. We recalculate these latter permeability values using water temperatures of $50^{\circ} \mathrm{C}$ and find the permeability to be $2.6 \times 10^{-15} \mathrm{~m}^{2}$, and $1.9 \times 10^{-15} \mathrm{~m}^{2}$, respectively.
Table 1. Hole 504B permeability calculation at $4010 \mathrm{~m}$ packer depth, $749 \mathrm{~m}$ above total depth.

\begin{tabular}{|c|c|c|c|c|c|}
\hline Pulse & $\begin{array}{c}\alpha \\
\left(10^{x}\right) \\
\text { where } \\
x=\end{array}$ & $\begin{array}{l}t_{0} \\
(\mathrm{~s})\end{array}$ & $\begin{array}{c}\mathrm{T} \\
\left(\mathrm{cm}^{2} / \mathrm{s}\right)\end{array}$ & $\begin{array}{l}\text { Avg. Temp. } \\
\left({ }^{\circ} \mathrm{C}\right)\end{array}$ & $\left(\times 10^{-k} \mathrm{~m}^{2}\right)$ \\
\hline \multirow[t]{3}{*}{1} & -2 & 330 & 3.25 & 90 & 1.2 \\
\hline & -1 & 225 & 4.78 & 60 & 2.6 \\
\hline & -3 & 660 & 1.63 & 120 & 0.5 \\
\hline \multirow[t]{3}{*}{2} & -2 & 300 & 3.6 & 90 & 1.4 \\
\hline & -1 & 200 & 5.3 & 60 & 2.9 \\
\hline & -3 & 700 & 1.5 & 120 & 0.4 \\
\hline \multirow[t]{3}{*}{3} & -2 & 450 & 2.4 & 90 & 0.9 \\
\hline & -1 & 260 & 4.1 & 60 & 2.3 \\
\hline & -3 & 1050 & 1.02 & 120 & 0.3 \\
\hline
\end{tabular}

\section{DISCUSSION}

The successful packer seat during Leg 83 gave good results-the curve fits were excellent for all three slug tests conducted over the lower $749 \mathrm{~m}$ of the hole, and the error estimates for each test overlap those for the others. The primary cause for error, that is, unknown temperatures of injected fluid, will be difficult to reduce in future testing because even if a temperature sensor is included with the downhole pressure gauge, the temperature profile below the packer sill will be undeterminable.

The most important result of the hydrological measurements in Hole 504B is the drop in bulk permeability from approximately $1.0^{-13}$ to $10^{-14} \mathrm{~m}^{2}$ in Layer $2 \mathrm{~A}$ to $10^{-15} \mathrm{~m}^{2}$ at the top of Layer $2 \mathrm{~B}$ to $10^{-17} \mathrm{~m}^{2}$ over Layers $2 \mathrm{~B}$ and $2 \mathrm{C}$ (Fig. 6). Extrapolation of the observed decrease into Layer 3 would predict gabbroic permeability to be less than $10^{-19} \mathrm{~m}^{2}$. Such an extrapolation is unwarranted now because, to our knowledge, few in situ measurements of permeability in gabbros of any kind have ever been made. However, the major drinking-water supply on Cyprus is from the gabbroic layers of the Troodos ophiolite, widely held to represent the ancient seafloor. This implies high present-day permeability for Layer 3 of the Troodos ophiolite and might suggest similarly high permeabilities while it was beneath the sea.

We can estimate the decrease in permeability versus depth by curve fitting to the measurements in Hole 504B. Because of the large depth intervals over which most of the measurements were made, such a curve is "pinned" only at the 190-210 m sub-basement measurement point. However, an average rate of decrease of permeability with depth can be calculated from a least-squares fit to the permeability at the top of each measurement interval. This assumption implies, in effect, that permeability decreases exponentially with depth, and that most of the fluid injected into the large test intervals permeates into the top of the interval. Keeping in mind these strong assumptions, the following relation results (Fig. 6):

$$
k(z)=0.11 e^{(-z / 50)} \times 10^{-12} \mathrm{~m}^{2}
$$

This equation probably results in a permeability estimate accurate to an order of magnitude in Hole 504B. The quality of the relation would be improved greatly with another point as deep as possible in the hole. Another drilling ship is scheduled to occupy Hole 504B in 


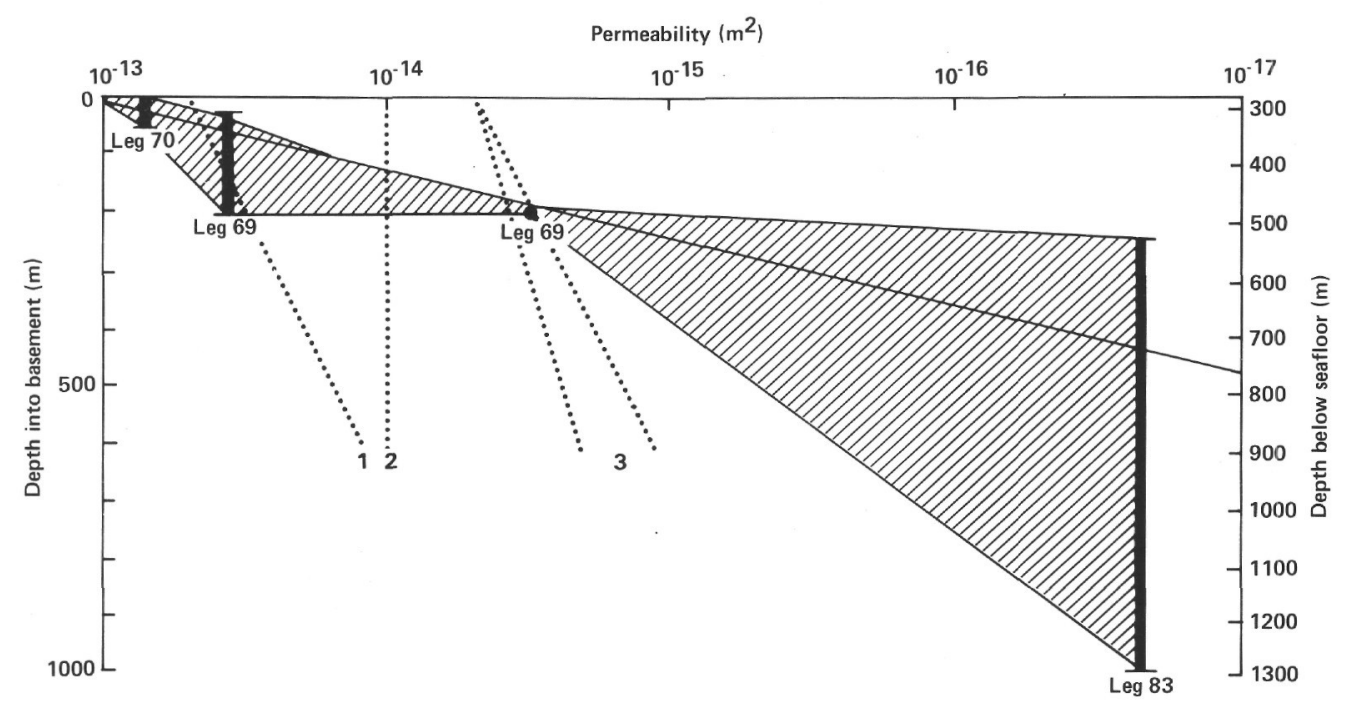

Figure 6. Measurements of permeability from Hole 504B from this paper, Anderson and Zoback, 1982, and Becker et al., 1983, plotted versus depth. Shading indicates uncertainty in permeability versus depth function caused by widths of the various intervals over which permeability was measured. Numbers refer to guesses of this function from Ribando et al., 1976 (1); Gartling and Anderson, in press (2); and two models from Fehn et al., 1983 (3). The solid line is least-squares curve fit to permeability values at the shallowest depth of each test (equation given in text).

1986 as part of the next phase of ocean drilling. Such a permeability experiment should be of the highest priority.

Although we have no idea at this time how representative Hole 504B is of the rest of the worldwide oceanic crust, we can compare these first permeability versus depth measurements with functions used in theoretical models for convection in the oceanic crust. Three "guesses" used in theoretical models are displayed against the measurements in Hole 504B in Figure 6. Number 1 is from Ribando et al. (1976), Number 2 is from Gartling and Anderson (in press), and Number 3 represents two different models presented by Fehn et al. (1983). All have significantly underestimated permeability in Layer $2 \mathrm{~A}$ and overestimated permeability in Layers $2 \mathrm{~B}$ and $2 \mathrm{C}$.

Use of our experimentally derived $\mathrm{k}(z)$ function within their models would probably produce more vigorous shallow circulation within the pillow basalts of Layer $2 \mathrm{~A}$ and more sluggish flow within the sheeted dikes of Layer $2 \mathrm{C}$.

Another important unknown in the permeability versus depth function is the time frame. We have no evidence with which to add time dependence to the Hole 504B results, let alone to a general relation. The alteration history of the minerals found in cores from Layer $2 \mathrm{C}$ clearly indicate a previous higher temperature history, followed by much colder conditions than those currently found in the hole (Alt and Laverne, this volume). Both colder and hotter circulation systems imply that the permeability in Layer $2 \mathrm{C}$ was higher, and the circulation was more vigorous in the past than at present. That is, high temperatures were probably present right at the ridge axis when mineralization responsible for the stockwork at the dike/pillow boundary was formed. The colder circulation phase is seen on all ridge flanks as lower than expected surface heat flow (Anderson et al., 1977).
High permeabilities are required to cool the dikes to temperatures lower than those presently encountered.

The reheating of Layer $2 \mathrm{C}$ could result from either sealing of the circulation system at the sediment/basement interface by the formation of chert, and/or a precipitous drop in bulk permeability caused by the precipitation of alteration minerals within the fracture system in the dikes (Anderson and Zoback, 1982). These two explanations are not mutually exclusive since sealing from above would cause hydrothermal fluids to circulate several times within a closed system. Increased temperature and accelerated mineral precipitation both would be enhanced.

\section{“REMOTE DETECTION" OF PERMEABILITY USING GEOPHYSICAL LOGS}

It is necessary to speculate about ways to derive permeability from other means than by flow tests because the likelihood of ever accumulating enough experimental data from packer experiments during deep-sea drilling is small. The equipment is expensive, the experiments are time consuming, and the probability of mechanical malfunctions is high. The most likely data set from which to derive permeability information is geophysical logging. In situ measurements of the absorption characteristics of the formation to neutron and gamma-ray bombardment reveal the location and concentration of alteration minerals and free-water porosity (Anderson et al., this volume). Electrical resistivity sourcereceiver arrays of differing lengths map the porosity of the crust over distances away from the well bore ranging from a few centimeters to tens of meters (Becker et al., 1982; Becker, this volume). Full waveform recording of sonic energy at multiple receivers provides a mechanism for determining the "acoustic permeability" of the for- 
mation and for estimating the average length and width of interconnected fractures responsible for energy loss into the formation (Anderson et al., this volume). Ultrasonic borehole imaging provides visual proof of fracture size and distribution (Newmark et al., this volume). A mechanism must be developed for integrating these geophysical logging results with regional geophysical surveys and core observations to provide a framework for estimating permeability in the crust.

The first problem has to do with scales of fracturing. Surface seismic refraction experiments determine velocities from sound sources of $10-100 \mathrm{~Hz}$ frequency. Velocities from sonic logging are determined from source frequencies of about $10 \mathrm{kHz}$, and laboratory measurements of velocity come from transmission of ultra-high-frequency sound. The intercomparison of the velocities from these three different experiments gives some idea of the predominance of fractures appropriate to the wavelengths of each measurement. If logging velocities are similar to surface refraction velocities, as is the case in Hole 504B (Stephen and Harding, 1983; Newmark et al., this volume), then fractures of less than $1 \mathrm{~m}$ in length must form an interconnected framework that extends several hundred meters away from the borehole for velocities from energies of such disparate wavelengths to be similar. If velocities from laboratory measurements on cores are also too high to be consistent with either sonic logging or refraction results, as is the case in Hole 504B, fractures not sampled within the cores must control the propagation of sound in the oceanic crust at least in Hole 504B. That is, small fractures are required to slow velocities at the short wavelengths of the sonic log, but these fractures must be uniform over a large area to slow the velocities at the long wavelengths of the seismic survey.

In fact, the velocity results from Hole 504B generally hold for fractured crystalline rocks. For example, Moos and Zoback (1983) found that logging velocities were consistent with refraction velocities, but considerably lower than laboratory measurements of velocities on cores of granite from a Mohave Desert well bore. It appears that the propagation of sound in crystalline media is controlled by interconnected macrofractures on the order of $1 \mathrm{~m}$ in length and $1 \mathrm{~mm}$ to $1 \mathrm{~cm}$ in aperture (Moos and Zoback, 1983; Seeburger and Zoback, 1982). We need to determine the hydraulic permeability of these fractures by some measure of the porosity of the rock. As with the acoustic experiments, electrical resistivity measurements at several different wavelengths can be used to estimate the scale of porosity. In Hole 504B, the porosity determined from long-spacing resistivity measurements over tens of meters of the borehole agrees well with porosities calculated from the spherically focused laterolog, a device that penetrates only a few tens of centimeters into the formation.

But additional tests need to be applied to the porosity calculation based upon resistivity logging to determine if the porosity is due to fractures, and if so, whether those fractures are indeed open to hydraulic flow. We use the BHTV to produce an image of the well bore (Zoback and Anderson, 1982). A fracture log derived from the
BHTV (Newmark et al., this volume) can then be compared to the porosity curves (Fig. 7). If they track each other down the hole, then it is likely that the porosity resides within fractures in the rock.

Consider the BHTV fracture density and resistivity logs of Figure 7. Both decrease from Layer 2A to reach a minimum at the top of Layer $2 \mathrm{~B}$. They then increase into Layer $2 \mathrm{~B}$, only to drop to another minimum at the top of Layer $2 \mathrm{C}$. The little porosity in the dikes most likely resides in the fractures still seen in abundance in the televiewer fracture log (Fig. 7).

The nuclear logs provide a final piece of information crucial to the tie between fracture porosity and permeability. The variation in alteration mineral, or "clay content," from the nuclear log cross-correlation of neutron porosity versus gamma-ray porosity (Anderson et al., this volume) will indicate the extent to which fractures are filled with alteration minerals when compared with the BHTV fracture-log and the porosity log determined from the electrical resistivity log. For example, porosity and fracture count are high in Layer $2 \mathrm{~A}$, but the alteration log indicates fewer clay minerals are present than in Layer 2B (Fig. 7). High permeability could be expected in this zone. Layer $2 \mathrm{~B}$ has lower permeability as the combined analysis of the logs would predict. The porosity drops in Layer $2 \mathrm{~B}$, the fracture count first decreases and then increases, but the clay content increases greatly (Fig. 7), indicating that fractures are clogged more substantially with alteration products in Layer 2B than in Layer $2 \mathrm{~A}$. The precipitous drop in permeability in Layer $2 \mathrm{C}$ can also be predicted from the logs; the porosity drops significantly, the fracture count drops a little, and the clay content remains relatively high (Fig. 7).

\section{PREDICTION OF PERMEABILITY IN OTHER DSDP BOREHOLES}

Becker et al. (1983) plotted permeability on the same graph as porosity derived from their long-spacing electrical resistivity experiment and suggested that the two were directly related. We have expanded the correlation in Hole 504B to include other geophysical logs. But can reasonable predictions be made at other sites where permeability measurements have not yet been made?

We begin in Hole 395A, the only other hole where in situ permeability measurements have been made in the oceans, just off the axis of the Mid-Atlantic Ridge (Fig. 8). Hickman et al. (in press) measured permeability values of 3 to $9 \times 10^{-18} \mathrm{~m}^{2}$ at $490-571 \mathrm{~m}$ sub-basement, and they estimate values several orders of magnitude higher in the shallow crust at that site based upon draw-down of ocean bottom water into an underpressured Layer 2A. Although the geophysical logging results were of much poorer quality in Hole 395A than in Hole 504B, a reasonably accurate electrical resistivity log was obtained (Fig. 9). Here, as in Hole 504B, we see both low apparent resistivity where permeability may be high and a dramatic increase in resistivity to values that indicate very low porosities at the bottom of the hole, where permeability was low (Fig. 9). In fact, the resistivity is higher than in Hole 504B (after taking into account the higher temperature in Hole 504B; see following) just as 


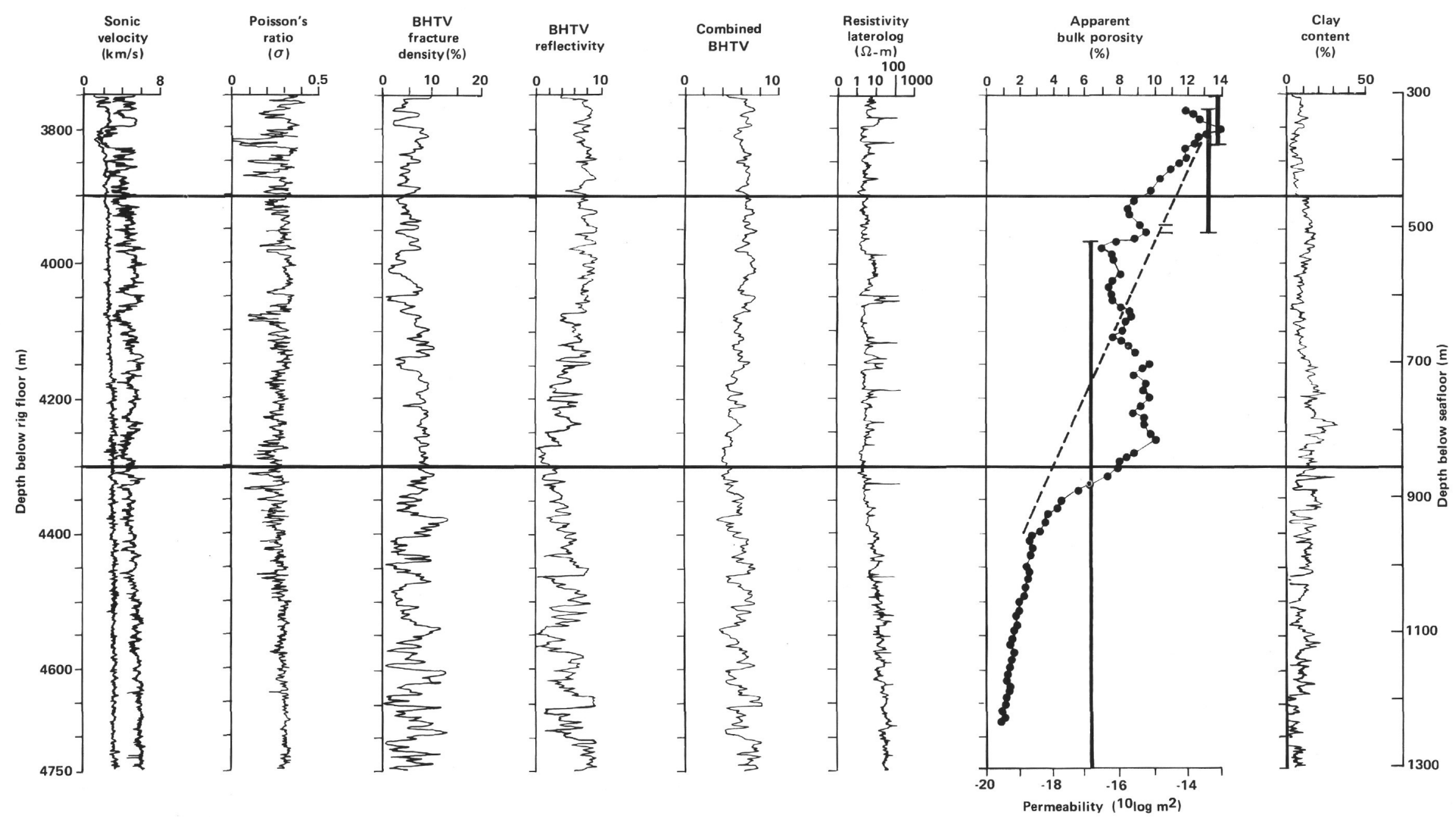

Figure 7. Geophysical logs from Hole 504B that record physical properties relevant to the determination of permeability. See Newmark et al., this volume, for explanation of first six curves; Becker et al., 1982, and Becker, this volume, for the porosity curve derived from long-spacing electrical resistivity; Becker et al., 1983, for the porosity-permeability similarity; and Anderson et al., this volume, for the derivation of the clay content log. The permeability versus depth measurements from Figure 6 are plotted on the porosity-permeability log, and the dashed line is the leastsquares curve fit from Figure 6. 


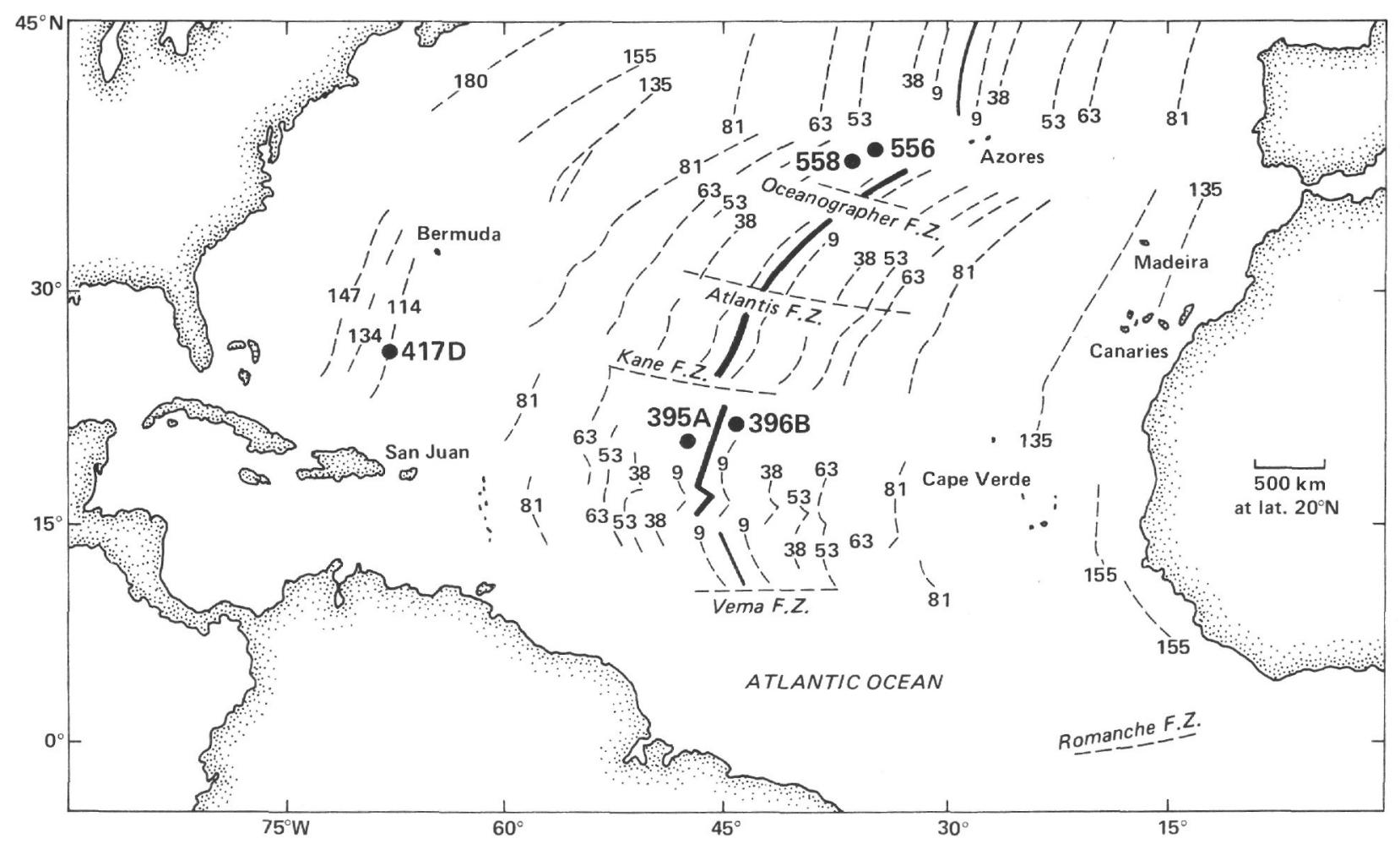

Figure 8. Location map for the DSDP holes from the Atlantic used in Figure 9 (from Hickman et al., in press). Hole locations are 396B $\left(23.05^{\prime} \mathrm{N}, 43.30^{\prime} \mathrm{W}\right) ; 417 \mathrm{D}\left(25.04^{\prime} \mathrm{N}, 68.05^{\prime} \mathrm{W}\right) ; 395 \mathrm{~A}\left(22.45^{\prime} \mathrm{N}, 46.05^{\prime} \mathrm{W}\right) ; 556\left(38.56^{\prime} \mathrm{N}, 34.41^{\prime} \mathrm{W}\right)$; and $558\left(37.46^{\prime} \mathrm{N}, 37.21^{\prime} \mathrm{W}\right)$.

the permeability is lower, although some of this discrepancy is caused by the difference in borehole temperatures between the two wells.

The conversion from electrical resistivity to porosity is strongly temperature dependent (cf. Von Herzen et al., 1983); and, therefore, good temperature versus depth information is required in a geothermally hot borehole such as Hole 504B. All of the Atlantic boreholes referred to in this chapter, however, are cold throughout, so an intercomparison of resistivities between the Atlantic holes is an accurate measure of porosity variations (Fig. 9B). Increased temperatures decrease the electrical resistivity of the pore fluid, so Hole 504B resistivities are lower than if normalized to a cold "Atlantic standard" (Fig. 9A versus 9B). It was not necessary to correct the Atlantic electrical resistivity logs for temperature because all were cold. We then predicted permeability in the Atlantic boreholes from uncorrected electrical resistivity logging results instead of from calculated porosities as in Hole 504B (Fig. 9B). The permeability predicted in this manner is roughly consistent with the permeabilities at the bottom of Hole 395A measured by Hickman et al. (in press).

In order to have much faith in predictions of permeability based upon resistivity logging, other logs such as nuclear, sonic, and borehole televiewer should be available, but there are no other holes in the oceans now where such a geophysical logging program has been successfully carried out. In fact, there are only four other boreholes-Holes 396B, 417D, 556, and 558, all in the Atlantic-for which reliable electrical resistivity logs exist in the oceanic crust. These show resistivities consis- tent with permeability values measured at the two holes in which experiments have been carried out (Fig. 9B). They predict permeability in the shallow Atlantic Ocean crust to be closer to that measured in Layers $2 \mathrm{~A}$ and $2 \mathrm{~B}$ in Hole 504B and inferred for the shallow crust in Hole $395 \mathrm{~A}$, rather than the lower values measured at the bottom of both holes.

\section{SUMMARY}

Hickman et al. (in press) concluded that if the 3 to $9 \times 10^{-18} \mathrm{~m}^{2}$ permeabilities measured at the bottom of Hole $395 \mathrm{~A}$ are pervasive, this would strongly inhibit the vertical extent of convective heat transfer in the ocean crust. We see that the permeability at $490-571 \mathrm{~m}$ into basement in Hole $395 \mathrm{~A}$ is slightly less than that measured from 250 to $999 \mathrm{~m}$ sub-basement in Hole 504B (Fig. 9). However, both measurements indicate permeabilities of approximately the same magnitude and imply that hydrothermal circulation might be strongly inhibited in the deeper oceanic crust at either site.

The other Atlantic holes examined (Fig. 9), including Hole 396B in seafloor of similar age (Fig. 8), predict permeabilities of $10^{-16} \mathrm{~m}^{2}$ or higher in Layers $2 \mathrm{~A}$ and $2 \mathrm{~B}$, so the electrical resistivity permeability analogy would strengthen the argument for the high permeability of the shallow oceanic crust.

We have developed a conceptual analogy for extending the difficult and time-consuming task of measuring oceanic crustal permeabilities in situ to the more readily accessible "fracture-porosity" determination using electrical resistivity and other geophysical logs. An internally consistent cross-correlation among the extensive 
A
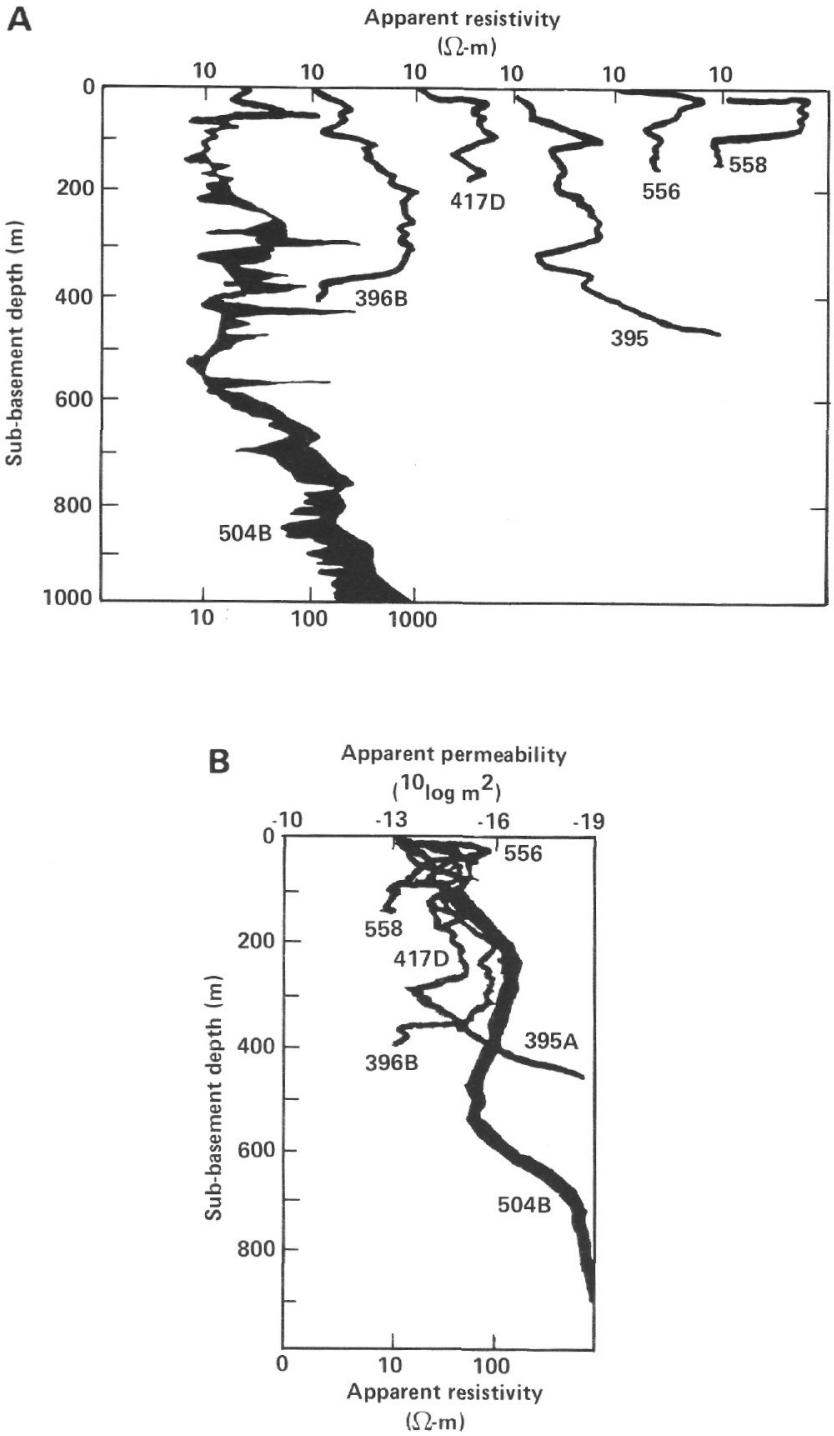

Figure 9. (A) Apparent resistivities from laterologs run in DSDP holes located in Figure 8, together with resistivity from Hole 504B. Shading in Hole 504B log is the difference between long-spacing $(10 \mathrm{~m})$ electrical resistivity log from Becker et al., 1982 (left) and spherically focused laterolog shown in Figure 7. (B) Apparent permeability and resistivity versus depth from relation derived by Becker et al., 1983, and shown in Figure 7. Temperature correction to electrical resistivity log in Hole 504B in Figure 9A results in solid curve in Figure 9B. The Atlantic logs are all from cold boreholes, and no temperature correction is required. Predicted permeabilities in Holes $556,558,417 \mathrm{D}$, and $396 \mathrm{~B}$ are $10^{-13}$ to $10^{-16} \mathrm{~m}^{2}$. The extremely low permeability predicted at the bottom of Hole $395 \mathrm{~A}$ by the resistivity log was measured by Hickman et al. (in press).

suite of in situ geophysical experiments in Hole 504B demonstrated that permeability in Layer 2 basalts is controlled by fracture density and the degree to which those fractures are infilled by alteration products. "Fracture porosity" derived from the electrical resistivity logs directly measures these changes downhole, and thus, at least in this hole, can be used to predict permeability. We tested this hypothesis at the only other ocean crustal site where electrical resistivity and in situ permeability were both measured, and we found that it predicts the extremely low permeabilities measured at $490-570 \mathrm{~m}$ subbasement depth at Mid-Atlantic Ridge Hole 395A.

We applied the predicted permeability versus depth variation in the shallow crust to four other Mid-Atlantic Ridge sites. They suggest values of $10^{-13}$ to $10^{-16} \mathrm{~m}^{2}$ for the upper part of Layer 2. We do not yet have enough high-quality electrical resistivity logging results to test the variation with age of permeability (or even of electrical resistivity and other logs) in the Atlantic. Holes 556 and 558 are in 37-Ma seafloor, Holes 395A and 396B in 7-Ma crust, and Hole 417D is 100 Ma old.

The model provides us with hope for the future. Geophysical logging will become standard in every drill hole of the next phase of deep ocean drilling, whereas in situ permeability measurements will not be done routinely. Instead, these measurements can be made selectively to further substantiate the fracture porosity permeability analogy. Thus, we end with a real hope that the next 10 years will lead to a profound understanding of the variation of permeability with depth and age in the oceanic crust and, subsequently, of the hydrothermal convection system it controls.

\section{ACKNOWLEDGMENTS}

We thank the officers and crew of the Glomar Challenger for the diligence and hard work necessary to carry out these experiments. We especially thank Pat Thompson of the Deep Sea Drilling Project for extraordinary effort on our behalf. This work was supported by National Science Foundation Grant OCE-81-10919.

\section{REFERENCES}

Anderson, R. N., Hobart, M. A., and Langseth, M.G., 1979. Geothermal convection through the oceanic crust and sediments in the Indian Ocean. Science, 204:828-832.

Anderson, R. N., Honnorez, J., Becker, K., Adamson, A. C., Alt, J. C., Emmermann, R., Kemptner, P. D., Kinoshita, H., Laverne, C., Mottl., M. J., and Newmark, R. L., 1982. DSDP Hole 504B, the first reference section over $1 \mathrm{~km}$ through Layer 2 of the oceanic crust. Nature, 300:589-594.

Anderson, R. N., Langseth, M. G., and Sclater, J. G., 1977. The mechanisms of heat transfer through the floor of the Indian Ocean. J. Geophys. Res., 82:3391-3409.

Anderson, R. N., and Zoback, M. D., 1982. Permeability, underpressures, and convection in the oceanic crust near the Costa Rica Rift, Eastern Equatorial Pacific, J. Geophys. Res., 87:2860-2868.

Becker, K., Langseth, M. G. Von Herzen, R. P., and Anderson, R. N., 1983. Deep crustal geothermal measurements, Hole 504B, Costa Rica Rift. J. Geophys. Res., 88:3447-3457.

Becker, K., Von Herzen, R. P., Francis, T. J. G., Anderson, R. N., Honnorez, J., Adamson, A. C., Alt, J. C., Emmermann, R., Kempton, P. D., Kinoshita, H., Laverne, C., Mottl, M .J., and Newmark, R. L., 1982. In situ electrical resistivity and bulk porosity of the oceanic crust, Costa Rica Rift. Nature, 300:594-598.

Bredehoeft, J. D., and Papadopulos, I. S., 1980. A method for determining the hydraulic properties of tight formations. Water Res. Res., 16:233-238.

Cooper, H. H., Jr., Bredehoeft, J. D., and Papadopulos, I. S., 1967. Response of a finite diameter well to an instantaneous charge of water. Water Res. Res., 3:267-269.

Fehn, U., Green, K. E., Von Herzen, R. P., and Cathles, L. M., 1983. Numerical models for the hydrothermal field at the Galapagos Spreading Center. J. Geophys. Res, 88:1033-1048.

Gartling, D. K., 1977. Convective heat transfer analysis by the finite element method. Comp. Methods Appl. Mech. Engr., 12:365-382.

Gartling, D. K., and Anderson, R. N., in press. Finite element analysis of convection in oceanic crust and sediments. J. Geophys. Res.

Gartling, D. K., and Hickox, C. E., 1979. MARIAH-A finite element program for incompressible porous flow problems, SAND791622, Sandia Labs, Albuquerque, N.M. 
Hickman, S. H., Langseth, M. G., and Svitek, J. F., in press. In situ permeability and pore pressure measurements near the Mid-Atlantic Ridge, DSDP Site 395. J. Geophys. Res.

Macdonald, K. C., and Luyendyk, B. P., 1981. The crest of the East Pacific Rise. Sci. Am., 244:100-117.

Moos, D., and Zoback, M. D., 1983. In situ studies of velocity in fractured crystalline rock. J. Geophys. Res., 88:2345-2358.

Papadopolos, I. S., Bredehoeft, J. D., and Cooper, H. H., 1973. On the analysis of slug test data. Water Res. Res., 9:1087-1089.

Ribando, R. J., Torrence, K. E., and Turcotte, D. L., 1976. Numerical models for hydrothermal circulation in the oceanic crust, J. Geophys. Res., 81:3007-3012.

Sayles, F., and Jenkins, W., 1982. Helium and radon anomalies caused by convection of pore waters in sediments from the Guatemala Basin. Science, 217:245-248.

Seeburger, D. A., and Zoback, M. D., 1982. The distribution of natural fractures and joints at depth in crystalline rock. J. Geophys. Res., 87:5517-5534.
Stephen, R. A., and Harding, A. J., 1983. Borehole seismic experiments and the structure of the upper oceanic crust. J. Geophys. Res., 88:8289-8298.

Von Herzen, R. P., Francis, T. J. G., and Becker, K., 1983. In situ large-scale electrical resistivity of ocean crust, Hole 504B. In Cann, J. R., Langseth, M. G., Honnorez, J., Von Herzen, R. P., White, S. M., et al., Init. Repts. DSDP, 69: Washington (U.S. Govt. Printing Office), 237-244.

Zoback, M., and Anderson, R. N., 1983. The implications of fracture distribution, structure, and stratigraphy from borehole televiewer imagery of the oceanic crust on the Costa Rica Rift. Nature, 295: 375-379.

Date of Initial Receipt: 18 June 1983

Date of Acceptance: 6 March 1984 